Tarbawy : Jurnal Pendidikan Islam

ISSN : 2407-4462 (Cetak), 2614-5812 (Elektronik)

Vol. 6, No. 1, 2019, Hal. 29 - 34

DOI: https://doi.org/10.32923/tarbawy.v6i1.862

\title{
Pemanfaatan Media Bahan Alam Daun Menyirip Dalam Mengenalkan Calistung Pada Anak Usia Dini
}

\author{
Dwi Haryanti ${ }^{1}$, Yesy Ustarina ${ }^{2}$ \\ ${ }^{12}$ IAIN Syaikh Abdurrahman Siddik Bangka Belitung
}

\begin{tabular}{ll}
\hline \hline Info Artikel : & \\
\hline & \\
Diterima & $: 3$ Mei 2019 \\
Direvisi & $: 26$ Mei 2019 \\
Dipublish & $: 28$ Juni 2019
\end{tabular}

\section{Kata Kunci: \\ Media \\ Anak Usia Dini}

Keywords:

Media

Childhood

\begin{abstract}
ABSTRAK ( 9PT)
Membaca, menulis, dan berhitung atau calistung bukanlah tahapan perkembangan kemampuan keterampilan yang dapat begitu saja dikuasai anak. Calistung adalah tahapan dasar orang bisa mengenal huruf dan angka dimana membaca merupakan suatu proses rumit yang melibatkan aktivitas auditif (pendengaran) dan visual (penglihatan) untuk memperoleh makna dari simbol berupa huruf atau kata. Daun menyirip merupakan media bahan alam yang digunakan sebagai media pengenalan calistung di RA Hadiqotul Amin Puding Besar. Media ini adalah salah satu yang bisa digunakan oleh guru dalam perkembangan calistung anak usia $5-6$ tahun. Penelitian ini adalah penelitian lapangan atau (field research) yang dianalisis secara deskriptif kualitatif dengan mendeskripsikan dan memaparkan data yang diperoleh dari hasil wawancara, catatan lapangan, dan dokumentasi. Hasil penelitian menunjukkan bahwa media bahan alam (daun menyirip) dapat menjadi media dalam mengenalkan membaca, menulis dan berhitung untuk anak usia dini, apalagi anak usia prasekolah, yakni 5-6 tahun. Anak dapat belajar langsung untuk melihat benda konkret tanpa harus menerka dari sebuah gambar. Media bahan alam merupakan media yang baik untuk digunakan dalam mengenalkan calistung pada anak usia dini. Harapannya guru dapat meningkatkan kreatifitasnya lagi dalam meningkatkan pembelajaran yang aktif dan menyenangkan sehingga tujuan pembelajaran bisa tercapai dengan baik.
\end{abstract}

\begin{abstract}
ABSTRACK
Reading, writing, and arithmetic are not stages of the development of skills that children can quickly master. Reading, writing, and arithmetic is a fundamental stage where people can recognize letters and numbers where reading is a complex process involving auditory and visual activities to obtain meaning from symbols in the form of letters or words. The pinnate leaf is a medium of natural material used as an introduction to reading, writing, and arithmetic in $R A$ Hadiqotul Amin Puding Besar. This media is one that can be used by teachers in the development of reading, writing, and arithmetic children aged 5-6 years. This research is field research, which is analyzed descriptively qualitatively by describing and describing data obtained from interviews, field notes, and documentation. The results showed that the natural material media (pinnate leaves) could be a medium in introducing reading, writing, and arithmetic for early childhood, especially preschoolers, which are 5-6 years old. Children can learn directly to see concrete objects without having to guess from an image. Natural material media is an excellent medium to be used in introducing reading, writing, and arithmetic in early childhood. It is hoped that the teacher can increase his creativity again in increasing active and fun learning so that learning objectives can be adequately achieved.
\end{abstract}

This is an open access article distributed under the Creative Commons Attribution License, which permits unrestricted use, distribution, and reproduction in any medium, provided the original work is properly cited. (C2019 by author.

\section{Koresponden:}

Nama Penulis,

Email: nama@gmail.com

\section{Pendahuluan}

Usia dini yang disebut sebagai usia emas (golden age) merupakan sebuah persepsi yang penting pada anak usia dini, sehingga banyak orang tua dan guru berlomba dengan waktu untuk memberikan pengalaman belajar melalui "kegiatan atau pembelajaran akademik".(Istiyani, 2014) Persepsi yang kurang tepat tentang golden age mengakibatkan konsep bermain terabaikan.(Rachman, 2019) Tidak sedikit orang tua dan guru berlomba memberi pengalaman pembelajaran berbasis akademik yang mengkedepankan 
lembar atau buku kerja anak. Dalam situasi ini, aspek kognitif atau intelektual memperoleh situasi terbesar, sedangkan aspek lainnya seperti emosional sosial, dan seni hampir terabaikan.

Pernyataan di atas semakin meyakinkan dengan adanya fenomena upaya peningkatan kompetensi anak dalam membaca, menulis, dan menghitung pada anak usia dini.(Istiyani, 2014) Fenomena ini dilatarbelakangi adanya ketentuan seleksi masuk Sekolah Dasar (SD atau MI) dengan model membaca, menulis dan menghitung (calistung).(Istiyani, 2014) Apabila melihat peraturan yang berlaku di Indonesia, seperti yang diungkapkan dalam "Republika.co.id", oleh Direktur Jenderal Manajemen Pendidikan Dasar dan Menengah, Kementerian Pendidikan Nasional, Suyanto, menegaskan bahwa calon siswa SD dan SMP tidak boleh ditolak dalam penerimaan siswa baru. Pasalnya, di jenjang pendidikan tersebut masih merupakan hak belajar sembilan tahun. Dalam surat edaran Nomor: 1839 / C.C2/TU/2009 yang ditunjukan kepada para gubernur dan bupati/walikota di seluruh Indonesia, kriteria calon peserta didik $\mathrm{SD} / \mathrm{MI}$ berusia sekurang-kurangnya 6 (enam) tahun dilakukan atas dasar rekomendasi tertulis dari pihak yang berkompeten, seperti konselor sekolah/madrasah maupun psikolog. Pendidikan di TK adalah itu tempat untuk menumbuhkan keberanian anak untuk memenuhi rasa ingin tahunya atau tempat bermain. Praktik tes dalam seleksi calistung yang dilakukan sekolah untuk penerimaan siswa SD, menurutnya adalah pelanggaran.(Istiyani, 2014)

Dari penjelasan di atas, tujuan umum program taman kanak-kanak dan surat edaran Nomor:1839/C.C2/TU/2009 memberikan tanggapan yang berbeda mengenai calistung untuk anak usia dini sehingga menimbulkan pro dan kontra mengenai boleh atau tidaknya calistung untuk anak usia dini. Usia dini merupakan usia emas untuk menyerap berbagai materi termasuk membaca, menulis dan berhitung.(Soefandi \& Pramudya, 2009) Pada usia ini sangat diperlukan bimbingan dan arahan yang benar-benar dapat membantu masa depan mereka bersinar, karena pada usia inilah anak mempunyai kemampuan menangkap yang begitu besar dan perlu diasah. Setiap apa yang diarahkan tentu sangat penting untuk masa depan mereka terutama kemampuan membaca, menulis dan berhitung.

Kemampuan membaca, menulis dan berhitung diperlukan sampai akhir hayat, karena dalam suasana apapun dan keadaan apapun, kemampuan membaca, menulis dan berhitung diperlukan.(Ade Sessiani, 2007) Untuk itu perlu diarahkan dan dikembangkan sejak kecil. Untuk mengembangkan kemampuan membaca, menulis dan berhitung sejak dini bukanlah hal yang mudah dilakukan karena anak usia dini sangat peka terhadap rangsangan apapun. Jadi apapun yang kita kenalkan kepada mereka sejak kecil akan berpengaruh terhadap masa depan mereka nanti.

Menurut Montessori pada saat anak-anak mulai memasuki usia empat tahun, mereka akan belajar membaca dan menulis dengan sangat antusias, karena mereka masih berada di dalam periode kepekaan terhadap bahasa.(Istiyani, 2014) Pada usia ini anak baru saja menguasai bahasa secara tidak sadar, dan ingin belajar banyak hal pada tingkatan yang lebih sadar, dan aktifitas membaca dan menulis mengizinkan mereka melakukan hal ini. Sebaliknya, apabila anak harus menunggu sampai usia enam atau tujuh tahun untuk belajar bahasa tertulis seperti yang dilakukan di sekolah-sekolah, tugas ini akan lebih sulit karena periode kepekaan sudah berlalu.

Bloom mereview beberapa studi penting dalam bidang ini dan menyimpulkan bahwa antara umur dua sampai 10 tahun, anak-anak mengembangkan kemampuan kognitif seperti bahasa dan keterampilan yang dipelajari dari orang dewasa dan sosio-afektif seperti kebutuhan untuk berprestasi, perhatian, dan kebiasaan bekerja yang baik.(Musbikin, 2010) Jadi, masa anak-anak awal menjadi basis untuk perkembangan kejiwaan selanjutnya, meskipun dalam tingkat tertentu pengalaman-pengalaman yang datang belakangan dapat memodifikasi perkembangan yang fondasinya sudah diletakkan oleh pengalaman sebelumnya. Artinya pengalaman belajar anak itu sangat berpengaruh terhadap perkembangan kognitif anak termasuk dalam mengenalkan baca, tulis, dan hitung.

Mengingat begitu pentingnya kemampuan membaca, menulis, dan berhitung selanjutnya disingkat calistung bagi manusia, maka kemampuan ini perlu diperkenalkan dan diajarkan sejak dini. Di sinilah peran guru untuk memperkenalkan dan mengajarkan kemampuan calistung kepada anak usia dini dengan cara-cara yang menyenangkan dan dengan berbagai kreativitas yang dimiliki oleh guru. Guru adalah salah satu faktor utama yang menentukan mutu pendidikan. Gurulah yang berada di depan dalam menciptakan kualitas sumber daya manusia. Peran guru akan menghasilkan peserta didik yang berkualitas, baik secara akademis, skill, kematangan emosional, moral,dan spiritual.(Ulfah Maulidya, 2013)

Dengan demikian, menjadi guru PAUD dituntut untuk aktif, kreatif, dan inovatif dalam merancang media dan metode belajar anak, sehingga semua tuntutan belajar anak dapat terpenuhi, mudah dipahami 
dan selalu diingat oleh anak serta anak merasa senang. Karena bermain adalah belajar anak dan dengan bermain anak mudah dapat memahami pembelajaran, maka pendidik harus banyak permainan. Setiap kegiatan permainan adalah kesempatan bagi kita untuk menstimulasi kemampuan calistung anak.

Sigmund Freud dalam teori psikologinya mengatakan bahwa masa kecil seorang individu adalah masa terpenting dalam menentukan akan menjadi apakah ia kelak dalam kehidupannya.(Widyastuti, 2017) Apa yang anak amati dan rasakan merupakan pengalaman yang kelak akan menjadi fondasi kuat hingga dewasa nanti. Para ahli anak usia dini mengetahui bawa proses belajar dan mengembangkan diri adalah proses terus-menerus yang terakomodasi sepanjang hidupnya. Salah satu proses belajar dalam masyarakat mana pun ialah membaca, menulis dan berhitung. Proses ini berpuncak pada pemahaman bahasa atau simbol yang digunakan di masyarakat untuk berkomunikasi.

Besarnya tuntutan orangtua dalam hal baca, tulis dan hitung untuk persiapan anak masuk ke jenjang sekolah dasar menjadi tantangan baru bagi setiap tenaga pendidik yang ada di sekolah PAUD khususnya RA Hadiqotul Amin Kecamatan Puding Besar Propinsi Kepulauan Bangka Belitung. Dibutuhkan strategi khusus untuk mengenalkan baca, tulis dan hitung kepada anak usia dini agar tidak mengganggu psikologis belajar mereka, baik perencanaan pembelajaran maupun pelaksanaanya. Tidak jarang guru menggunakan metode yang membosankan bagi anak-anak dalam mengenalkan baca, tulis dan hitung pada anak usia dini sehingga mengganggu minat anak dalam menerima pembelajaran yang disampaikan. Kurangnya minat anak dalam hal calistung membuat guru berikhtiar mencari strategi yang tepat untuk anak-anak. Observasi awal di RA tersebut bahwa terindikasi pembelajaran yang dilakukan terkesan memaksa untuk mencapai tujuan pembelajaran yang diinginkan guru membuat anak-anak bosan dan enggan mengikuti pembelajaran yang diterapkan, sehingga guru berusaha berikhtiar merubah strategi yang pernah ada menjadi strategi yang baru baik secara metode maupun media dengan tujuan menciptakan pembelajaran yang menyenangkan dan tidak membosankan sehingga tujuan pembelajaran dapat tercapai sesuai harapan. Sebelumnya, para pendidik menggunakan media gambar dalam mengenalkan baca tulis dan hitung pada anak kelompok B. Akan tetapi berdasarkan wawancara penulis dengan pihak sekolah dengan mengenalkan baca, tulis dan hitung melalui gambar anak ada yang gagal paham dalam memahami gambar yang ditunjukkan pendidik. Hal inilah menjadi alasan penulis untuk meneliti lebih dalam bagaimana pemanfaatan media bahan alam daun menyirip dalam mengenalkan calistung untuk anak usia dini.

\section{Metode}

Penelitian yang dilakukan oleh penulis ini merupakan penelitian kualitatif dengan pendekatan deskriptif. Tujuan penelitian ini adalah mengungkapkan gejala secara holistik-kontekstual melalui pengumpulan data dari latar alami dengan memanfaatkan diri penelitian sebagai instrumen kunci.(Sugiarto, 2017) Sehingga dalam hal ini, penulis mendeskripsikan secara detail pemanfaatan bahan alam daun menyirip dalam mengenalkan calistung pada anak usia 5-6 tahun di RA Hadiqotul Amin Puding Besar. Informan dalam penelitian ini dipilih berdasarkan subjek penelitian yang terdiri dari kepala sekolah RA Hadiqotul Amin dan dua guru di RA Hadiqotul Amin.

Teknik pengumpulan data yang dilakukan melalui wawancara, observasi dan dokumentasi. Wawancara yang dilakukan merupakan wawancara terstruktur atau wawancara yang dilaksanakan secara terencana dengan berpedoman pada daftar pertanyaan yang telah dipersiapkan. Observasi pada penelitian ini dilakukan untuk mengumpulkan data secara langsung melalui pengamatan di RA Hadiqotul Amin Puding Besar Kecamatan Puding Besar Kabupaten Bangka untuk mengetahui pemanfaatan media bahan alam daun menyirip dalam mengenalkan calistung pada anak usia 5-6 tahun di RA Hadiqotul Amin Puding Besar. Sedangkan dokumentasi dalam penelitian ini berupa data sekolah, foto-foto tentang kegiatan anak-anak pada saat proses pembelajaran yang sedang berlangsung, RPPH, dan data siswa yang ada di RA Hadiqotul Amin Puding Besar kelompok B usia 5 - 6 tahun.

\section{Hasil dan Pembahasan}

Media merupakan alat peraga dalam menyampaikan tujuan pembelajaran kepada anak usia dini. Melalui media anak akan lebih mudah untuk memahami pembelajaran yang di sampaikan oleh guru. Media dapat di peroleh dari bahan sisa atau bahan alam. Seperti yang telah penulis jelaskan sebelumnya bahwa Sardiman menjelaskan guru-guru perlu menyadari sepenuhnya bahwa lingkungan sangat efektif sebagai sumber dan media bermain atau belajar.(Asmawati, 2014) 
Sebelum memulai pembelajaran tentunya guru sudah menyiapkan rencana pelaksanaan pembelajaran mingguan dan harian (RPPM dan RPPH) sesuai dengan tema. Guru juga sudah mengetahui konsep pembelajaran apa yang ingin disampaikan sehingga dalam proses pembelajaran tidak mempengaruhi hasil belajar siswa, maka dari itu satu upaya guru dalam merencanakan pebelajaran yaitu guru menyusun konsep pembelajaran mulai dari bahan ajar, tujuan dan peserta didik.

Dengan rencana pelaksanaan pembelajaran harian guru membuat konsep kegiatan yang dilakukan seperti indikator keberhasilan, pendidikan karakter, kegiatan pembelajaran, alat dan sumber belajar dan penilaian meliputi alat dan hasil. Kegiatan belajar mengajar di RA Hadiqotul Amin meliputi kegiatan awal 30 menit yaitu: berdo'a, bernyanyi, dan absensi siswa. Selanjutnya kegiatan inti 60 menit, kegiatan inti merupakan pelaksanaan pembelajarannya yang meliputi: tema, sub tema yang di bahas dengan bercakap-cakap membahas tema dan pokok kegiatan. Selanjutnya istirahat 30 menit meliputi: istirahat dan dilanjutkan makan, berdo'a dan pulang. Sebelum kegiatan belajar mengajar berlangsung anak-anak di minta untuk mengaji dan solat duha.

Rencana pelaksanaan pembelajaran disusun untuk mempermudah guru dalam proses belajar mengajar. Berhasilnya suatu pembelajaran tak lepas dari strategi guru dalam menyampaikan pembelajaran dari perencanaan sebagai petunjuk arah kegiatan dalam mencapai tujuan, sebagai pedoman kerja guru, alat ukur, mengatur waktu, tenaga, alat dan biaya.

Setelah menyusun komponen-komponen perencanaan pembelajaran, guru menyusun langkah-langkah persiapan belajar mengajar yang menerapkan pengenalan calistung sesuai dengan tema dalam proses pebelajaran. Langkah-langkah tersebut di antaranya adalah sebagai berikut:

Guru menyiapkan rancangan kegiatan harian atau rencana pelaksanaan pembelajaran harian (RPPH) yang akan disampaikan

Guru sudah menyiapkan media yang akan digunakan

Sebelum kegiatan inti dilakukan, guru memberi penjelasan untuk tema yang akan dilaksanakan.

Memberi gambaran secara visual kepada anak tentang peroyek yang akan-anak kerjakan (peroyek sesuai tema namun tetap menyangkut calistung)

Memberi contoh kepada anak tentang proyek yang akan di lakukan

Mengawasi dan memberikan dorongan kepada anak untuk menunjukkan kreativitas anak dan menyelsaikan proyeknya

Menilai hasil karya anak

Dalam setiap materi pembelajaran yang akan digunakan, guru selalu menggunakan berbagai macam metode. Metode yang digunakan dalam mengembangkan kemampuan calistung anak adalah melalui pendekatan kepada anak. Dalam hal membaca dan guru menggunakan metode Montessori yaitu menggabungkan huruf menjadi suku kata, suku kata menjadi kata dan kata menjadi kalimat. Guru juga menerapkan metode meniru dalam menulis dan membaca keras bersama-sama, Guru juga memberi kebebasan pada anak untuk mengungkapkan imajinasinya. Mengajak anak mengenal angka dan berhitung bersama.

Menurut Muhibbin, metode adalah cara yang berisi prosedur baku untuk menjelaskan kegiatan pendidikan, khusunya kegiatan penyajian materi pelajaran kepada anak. (Syah, 2010) Dalam penerapan metode oleh guru, biasanya guru terlebih dahulu menyusun metode tersebut ke dalam Rencana Pelaksanaan Pembelajaran Harian (RPPH). Hal ini bertujuan agar metode yang akan dilaksanakan oleh guru dapat berjalan secara efektif dan efisien. Begitu juga dalam pemanfaatan media bahan alam daun menyirip, sebelum guru melaksanakan pada proses pembelajaran di kelas, guru terlebih dahulu menyusun atau merancang kegiatan tersebut di dalam RPPH.

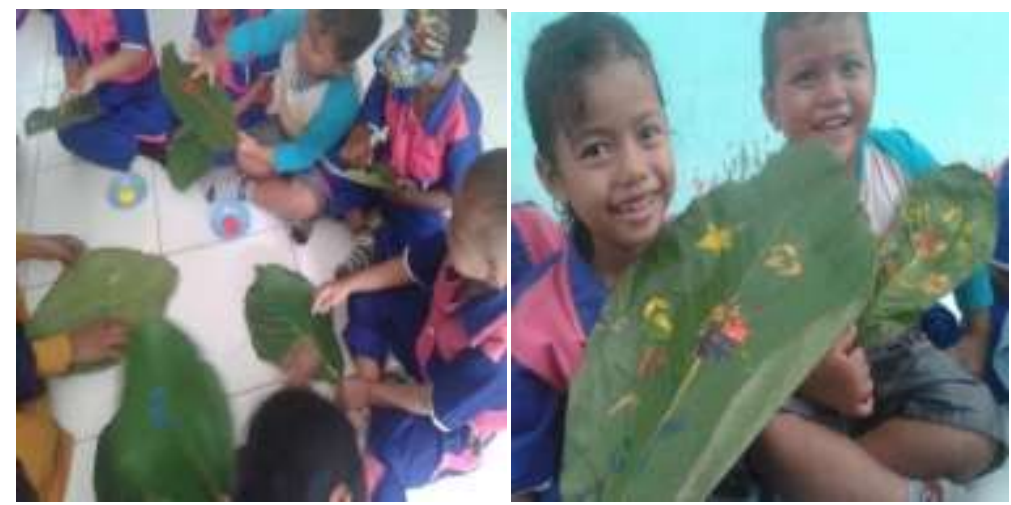

Gambar 1. 
Lingkungan di sekitar kita kaya akan sumber belajar. Guru hendaknya mampu memanfaatkan sumber belajar tersebut sebagai alat permainan edukatif. Seperti yang telah penulis jelaskan di bab sebelumnya Sardiman mengatakan bahwa guru-guru perlu menyadarkan sepenuhnya bahwa lingkungan sangat efektif sebagai sumber dan media bermain atau belajar. Secara kreatif guru dapat menggunakan alat peraga dan alat bantu belajar yang berasal dari lingkungan sekitar dan memanfaatkan barang-barang bekas sebagai sarana bermain dan belajar bagi anak.(Asmawati, 2014)

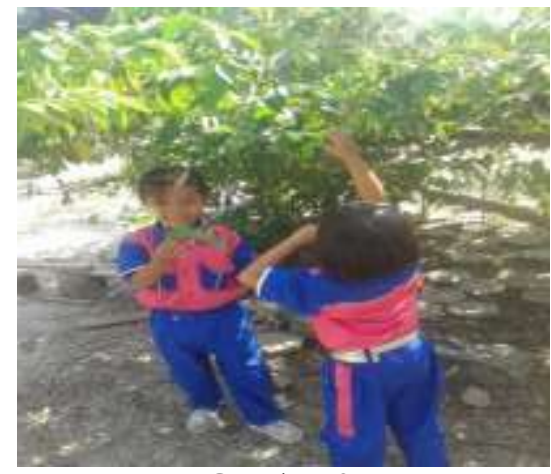

Gambar 2.

Anak Didik mengambil Daun Menyirip di Sekitar Sekolah dengan Menggunakan Metode Karyawisata

Persiapan membaca, menulis dan berhitung sangat penting bagi anak untuk belajar di tingkat yang lebih tinggi, namun pada tingkat kesiapan anak dan minat anak tetap harus diperhatikan. Memaksa anak untuk membaca, menulis dan berhitung saat dia belum siap sangat beresiko membuat anak frustasi. Glenn Doman mengatakan, bahwa kemampuan membaca pada anak usia dini banyak memengaruhi tingkat inteligensi.(Sujiono, Zainal, Rosmala, \& Tampiomas, 2014) Semakin dini seorang anak membaca, semakin cepat ia mampu membaca, semakin mampu ia membaca maka semakin gemar ia membaca.

Dari wawancara yang telah dilakukan, dapat disimpulkan bahwa, dengan adanya media bahan alam, metode dan strategi yang tepat maka pengenalan calistung pada anak usia dini akan mudah diterapkan. Selain metode dan strategi guru yang tepat motivasi belajar dari orangtua dan anak juga dibutuhkan dalam belajar. Daun menyirip bisa mengenalkan calistung secara langsung pada anak karena mempunyai banyak macamnya. Adapun proses pelaksanaan pembelajaran dalam kegiatan penerapan bahan alam dalam mengenalkan calistung untuk anak usia dini berdasarkan observasi penulis di RA Hadiqotul Amin, hal yang dilakukan seorang guru sebelum kegiatan belajar mengajar yaitu: (a) guru menyiapkan alat atau media; (b) tahap pelaksanaan; dan (c) tahap evaluasi. Pelaksanaan pembelajaran penerapan bahan alam dalam mengenalkan calistung untuk anak usia 5 - 6 tahun ini, menjadikan anak lebih antusias, bersemangat, menyenangkan serta dapat berkonsentrasi dan terfokus pada proses kegiatan pembelajaran. Pembelajaran sudah melibatkan anak untuk menjadi peserta didik yang aktif. Kegiatan calistung yang disajikan dapat mendorong anak untuk lebih kreatif, dalam hal ini anak mengalami peningkatan dan setelah diberikannya kegiatan ini secara bertahap, anak berada dalam kriteria baik.

\section{Kesimpulan}

Penggunaan media bahan alam (daun menyirip) dapat digunakan dalam mengenalkan calistung bagi anak usia dini. Peggunaan media bahan alam dengan metode yang tepat dapat meningkatkan motivasi anak dalam belajar. Dilihat dari penggunaan media sebelumnya, media daun menyirip dapat meningkatkan pengetahuan anak walaupun belum $100 \%$ berkembang sangat baik. Media bahan alam daun menyirip merupakan media yang mudah diperoleh dari lingkungan sekitar anak. Pengenalan membaca, menulis, dan berhitung pada anak usia dini dengan menggunakan media bahan alam daun menyirip dapat mengembangkan minat belajar anak sehingga anak tidak bosan dan frustasi terhadap proses pembelajaran yang berlangsung.

\section{Referensi}

Ade Sessiani, L. (2007). Pengaruh Metode Multisensori dalam Meningkatkan Kemampuan Membaca Permulaan pada Anak Taman Kanak-kanak (Studi Eksperimental di TK ABA 52 Semarang). Universitas Diponegoro. 
Asmawati, L. (2014). Perencanaan pembelajaran PAUD. Bandung: Remaja Rosdakarya.

Istiyani, D. (2014). Model pembelajaran membaca menulis menghitung (calistung) pada anak usia dini di kabupaten pekalongan. Jurnal Penelitian, 10(1).

Musbikin, I. (2010). Buku Pintar PAUD. Jogjakarta: Laksana.

Rachman, Y. A. (2019). MENGKAJI ULANG KEBIJAKAN CALISTUNG PADA ANAK USIA DINI. Jurnal Kajian Dan Pengembangan Umat, 2(2).

Soefandi, I., \& Pramudya, A. (2009). Strategi Mengembangkan Potensi Kecerdasan Anak. Jakarta: Bee Media Indonesia.

Sugiarto, E. (2017). Menyusun Proposal Penelitian Kualitatif: Skripsi dan Tesis: Suaka Media. Diandra Kreatif.

Sujiono, Y. N., Zainal, O. R., Rosmala, R., \& Tampiomas, E. L. (2014). Metode pengembangan kognitif.

Syah, M. (2010). Psikologi dengan Pendekatan Baru (Bandung: PT. Remaja Rosdakarya.

Ulfah Maulidya, S. (2013). Konsep Dasar PAUD. Bandung: PT Remaja Rosdakarya.

Widyastuti, A. (2017). Kiat Jitu Anak Gemar Baca Tulis. Elex Media Komputindo. 